20. Starinsky, R., and Shafrir, E.: Displacement of albumin-bound bilirubin by free fatty acids: Implications for neonatal hyperbilirubinemia. Clin. Chim. Acta, 29: 311 (1970).

21. Sterky, G.: Swedish standard curves for intrauterine growth. Pediatrics, 46: 7 (1970).

22. Trout, D. L., Estes, E. M., Jr., and Friedberg, S. J.: Titration of free fatty acids of plasma: a study of current methods and a new modification. J. Lipid Res., 1: 199 (1960).

23. Packard Tri-Carb, Packard Instrument Co., Downer's Grove, Ill.

24. Beckman Instruments, Palo Alto, Calif.

25. New England Nuclear Corp., Boston, Mass.

26. This study was partially supported by a grant from Föreningen

Copyright (c) 1975 International Pediatric Research Foundation, Inc.
Margarethahemmet, Semper Fund for Nutritional Research, the Swedish Medical Research Council (40X-2553, 40P-3828, 19X3787, 19P-4106, 04X-4496), “Expressen's" Prenatal Research Fund, and the Association of the Swedish Pharmaceutical Industry.

27. Miss Margareta Stensdotter, and Miss Gerd Lundqvist provided technical assistance.

28. Requests for reprints should be addressed to: Anders Rane, M.D., Department of Clinical Pharmacology, Karolinska Institutet, Huddinge Hospital, Flemingsbergsgatan, S-141 86, Huddinge, Stockholm, Sweden.

29. Accepted for publication July 26, 1974.

Printed in U.S.A.

Pediat. Res. 9: 30-34

Cellular replication

growth

mumps virus

\title{
The Biological and Biochemical Pathogenesis of Mumps Virus-induced Embryonic Growth Retardation
}

\author{
TERRY YAMAUCHI, ${ }^{(40)}$ JOSEPH W. ST. GEME, JR., WILLIAM OH, AND CATHERINE W. C. DAVIS
}

Department of Pediatrics, Harbor General Hospital, UCLA School of Medicine, Torrance, California, USA

\section{Extract}

Embryonic mumps virus infection in the avian host leads to fetal growth retardation. The mechanism of this retardation has not been established.

The avian host is unique in that the direct effect of a virus on the embryo may be ascertained in the absence of a placenta.

Using radioisotope labeling techniques, DNA, RNA, and protein metabolism was investigated in tissues from infected and control chickens. Metabolism in organ tissue cultivated in vitro and then infected was also studied using the same radioisotope techniques.

At hatch, the mean body weight of eight experimental chickens infected with mumps virus early during embryonic incubation was significantly less than that of 19 controls. This lower weight was evident in the brain of the infected chickens. The brain and carcass contained decreased amounts of RNA and protein when compared with uninfected control chickens. The kidney was the only other organ in which the protein content in experimental chickens was less than in controls.

There was no difference in the DNA content of organs from in ovo-infected and control chickens or organ tissues cultivated in vitro before infection with mumps virus. Similarly, measurements of cell number at the same time were equal.

Viral assay of the chickens infected in ovo revealed highest titers of virus in the heart throughout the last half of incubation. Intermediate titers of virus were recovered from the lung, spleen, and skeletal muscle. Low quantities of virus were recovered from the brain and liver. The bursa contained high titers of virus at midincubation but these titers rapidly declined by hatch.
Growth retardation in the mumps virus-infected chicken model is not due to a reduction in cell number but appears to be caused by a diminution in cell size.

\section{Speculation}

The relation between embryonic mumps virus infection and myocarditis is supported by the findings of high titers of virus throughout the incubation period. It is postulated that altered cardiac function results in a state of hypofusion and a preferential effect is seen in the brain with consequent diminution of cell size rather than cell number.

Embryonic growth retardation has been attributed to many factors, including metabolic defects (10), malnutrition of fetal and maternal origin $(20,24,25,32)$, congenital anomalies ( 3 , $21)$, and infection $(1,2,26)$. Under normal conditions the embryo grows as the population and size of cells increase. Conditions which impair either cellular variable will result in growth retardation. Several experimental models of fetal growth retardation in the mammal have been particularly illuminating. Wigglesworth (31) and Emmanouilides et al. (9) ligated the uterine and umbilical arteries of the rat and sheep, respectively, producing placental insufficiency which resulted in fetal growth retardation.

The avian model offers the opportunity for unique experimentation in that the direct effect of a virus on the chicken embryo may be ascertained in the absence of a placenta. Previous work has demonstrated that mumps virus infection during early embryonic life causes growth retardation of the embryo and newly hatched chicken (27). The 
mechanism of this altered growth is unclear. In this communication we wish to present a biological and biochemical analysis of mumps virus-induced avian growth retardation and to propose a possible pathogenetic mechanism.

The DNA, RNA, and protein content of infected and control chicken organs was determined in addition to the pattern of viral replication in embryonic organs throughout the last half of incubation. The kinetics of DNA, RNA, and protein metabolism and cellular multiplication were evaluated for tissues harvested from infected and control embryos as well as for cells cultivated from normal organs and those infected with mumps virus in vitro.

\section{MATERIALS AND METHODS}

VIRUS

The strain of mumps virus (Amaris) used in these experiments was isolated originally from a pregnant woman with parotitis and passaged 22 times in calf serum-adapted $\mathrm{HeLa}$ cells. The biologic characteristics of the Amaris strain of mumps virus have been described previously (14). The titers of stock virus varied from $10^{6}-10^{7}$ plaque-forming units $(\mathrm{PFU}) / \mathrm{ml})$. The inocula of virus per egg varied from $5 \times 10^{3}$ to $5 \times 10^{4}$ PFU. Control inocula consisted of spent HeLa cell culture medium prepared similarly to the mumps virus seed pool.

\section{EGGS}

Fertile eggs of the White Leghorn species (33) were incubated at $38^{\circ}$ and $98 \%$ relative humidity. Inoculation with mumps virus was performed at $16-18 \mathrm{hr}$ of age through the blunt end of the egg after the area had been decontaminated with $2 \%$ iodine and cleansed with $70 \%$ alcohol. A small hole was bored at the blunt end, a 1-inch, 23-gauge needle was inserted to the hub, and $0.05 \mathrm{ml}$ virus was injected with a tuberculin syringe. The defect was then sealed with sterile paraffin. Control eggs were inoculated in the same manner with spent medium. The eggs were re-incubated and rotated every $24 \mathrm{hr}$ from side to side.

\section{WEIGHT}

At hatch approximately 21 days after viral inoculation the chickens were weighed on a Sartorius analytic balance. Carcass weight was determined after removing the feet, beak, organs, and skin. Brain, liver, kidneys, and heart were weighed immediately after removal from the chicken. Lung was saved for viral assay.

\section{DNA, RNA, AND PROTEIN ASSAY}

Organs were homogenized in 5\% trichloroacetic acid (TCA) and the homogenates were assayed for DNA, RNA, and protein content by the methods described by Burton (4), Webb (29), and Lowry et al. (17), respectively. Infected and uninfected tissues were analyzed simultaneously.

\section{IN OVO INFECTION}

After 12 and 20 days of incubation, 12 infected and 12 control chick embryos were killed and the brain, heart, and portions of skeletal muscle were removed. The tissues were washed three times with buffered glucose, potassium, and sodium solution (G1KNa), minced, and trypsinized with $0.1 \%$ trypsin for 20-30 min on a mechanical stirrer. Cells were counted and diluted to 200,000 cells $/ \mathrm{ml}$ with growth medium containing Eagle's basal supplement in Hanks' balanced salt solution (BSS), 10\% heat-inactivated fetal bovine serum, and $100 \mathrm{U}$ penicillin and $100 \mu \mathrm{g}$ streptomycin $/ \mathrm{ml}$. Cells were plated into $16 \times 125$ tubes in $1-\mathrm{ml}$ volumes and incubated at $35^{\circ}$

\section{IN VITRO INFECTION}

After 12 to 20 days of incubation, 20 normal chicken embryos were killed. The brain, heart, and portions of skeletal muscle were removed and prepared as above. After the cells had settled on glass for $48 \mathrm{hr}$, one-half of the cultures were infected with $10^{5.5} \mathrm{PFU}$ mumps virus/culture and the remaining cells were used as uninfected control cultures.

\section{RADIOISOTOPE STUDIES}

Radioisotopic labeling was used to study the DNA, RNA, and protein metabolism in cells cultivated from organs infected in ovo, organ-derived cells infected in vitro, and noninfected cell cultures. To eliminate the possibility that differences in the kinetics of cellular metabolism were due to the effects of cellular maturation, a cell population derived from 12-day-old chicken embryos was compared with cells cultivated from 20-day-old chicken embryos. After 3 days of cultivation, the medium was poured off the cells and $0.5 \mu \mathrm{Ci}$ (specific activity of $500 \mu \mathrm{Ci} / \mathrm{ml}) \quad\left[{ }^{3} \mathrm{H}\right]$ thymidine, $[5-$ $\left.{ }^{3} \mathrm{H}\right]$ uridine, and L- $\left[4,5-{ }^{3} \mathrm{H}\right]$ leucine $(34)$ were added to replicate cultures. Three cultures of each organ infected in ovo, organ-derived cells infected in vitro, and noninfected organderived cells were heat-killed $\left(65^{\circ}\right.$ water bath, $\left.30 \mathrm{~min}\right)$ and used as an internal procedural control. Three replicate infected, control, and heat-inactivated cultures were isotopically labeled for $22 \mathrm{hr}$, at which time the isotope was poured off and the cells washed twice with phosphate-buffered saline with calcium and magnesium. One milliliter of Tris buffer, $0.05 \mathrm{M}, \mathrm{pH} 7.4$, was added to each culture. Cells were removed from the glass by repeated freezing and thawing with Dry Ice and $95 \%$ ethyl alcohol. One milliliter of $1 \mathrm{M}$ TCA was added and the fractured cells were allowed to precipitate for $3 \mathrm{hr}$ at $4^{\circ}$. The cells and cellular debris were centrifuged at $2,000 \mathrm{rpm}$ for $5 \mathrm{~min}$ at $4^{\circ}$. The excess fluid was poured off and the sediment was washed twice with $0.5 \mathrm{M}$ TCA. The precipitate was dissolved with $0.5 \mathrm{ml}$ tissue solubilizer. After mixing with $2 \mathrm{ml}$ toluene and scintillation fluid, the samples were transferred to individual plastic counter containers with an additional $13 \mathrm{ml}$ toluene and scintillation fluid. Triplicate samples were placed in a Nuclear Chicago liquid scintillation system (model 6848) and $\beta$ emission was counted for $10 \mathrm{~min}$ of 100,000 counts. Counts per minute per cell were calculated for each sample.

\section{VIRAL REPLICATION}

The pattern of viral replication throughout the last half of incubation was investigated in several organs of the infected embryo. On days 10,14, 17, and 20 of incubation, heart, brain, lung, bursa, liver, spleen, and skeletal muscle were removed from three to five embryos infected in ovo. The tissues were washed twice with buffered GIKNa, triturated and a $10 \%$ suspension prepared with maintenance medium (MM) consisting of Eagle's basal supplement in Hanks' BSS, 5\% fetal bovine serum, and antibiotics. Serial 10-fold dilutions of tissue suspensions in $0.3-\mathrm{ml}$ aliquots were added to $\mathrm{HeLa}$ cell monolayers in duplicate polystyrene flasks (35) and adsorbed for 2 hours. The inocula were decanted and the HeLa cells washed twice with buffered BSS. Three milliliters of MM were added and the flasks were re-incubated at $35^{\circ}$. After 4 days a $0.1 \%$ suspension of guinea pig erythrocytes was added to the flasks and the plaques were identified as hemadsorption foci (7). 
RESULTS

HUSBANDRY

Over a 5-year period, consisting of approximately 40 experiments, the hatch rate of control and infected chickens ranged from a low of $4 \%$ to a high of $60 \%$. The overall hatch rate was $30 \%$. Usually twice as many eggs inoculated with spent medium hatched as eggs inoculated with mumps virus. Hatch rates lower by $10-15 \%$ were obtained for eggs shipped by air. Uninoculated fertilized eggs hatched at a rate of $90 \%$. A consistent finding in multiple experiments was the striking escalation of death occurring over the final days of incubation in virus-infected embryos.

\section{WEIGHT AND BIOCHEMISTRY}

As detailed in Table 1, at hatch the mean body weight of infected chickens $(39.8 \pm 0.5 \mathrm{~g})$ was significantly less $(P<$ 0.005 , Student $t$ test) than that of controls $(43.7 \pm 1.0 \mathrm{~g})$. This lower weight was evident in the brain of the infected chickens $(560 \pm 138 \mathrm{mg})$ when compared with controls $(685 \pm 140 \mathrm{mg})$. The brain and carcass of experimental chickens had decreased RNA and protein content. The RNA content in the brain of infected chickens $(2.6 \pm 1.5 \mathrm{mg})$ was significantly less $(P<$ $0.05)$ than controls $(3.8 \pm 0.9 \mathrm{mg})$. Equally significant was the mean RNA content of the carcass from infected chickens (69 $\pm 46 \mathrm{mg}$ ) compared with controls $(145 \pm 60 \mathrm{mg})$. The mean protein content of brain from experimental chickens (62 \pm 27 $\mathrm{mg})$ was less $(P<0.05)$ than controls $(146.7 \pm 50 \mathrm{mg})$. Mean protein content of carcass from infected chickens was less than controls (3.4 $\pm 0.5 \mathrm{~g}$ versus $4.6 \pm 0.8 \mathrm{~g})$. The kidney of experimental chickens contained significantly less $(P<0.05)$ protein $(50.3 \pm 23.4 \mathrm{mg})$ than controls $(256 \pm 8.8 \mathrm{mg})$. The organ weight and RNA content of liver, kidney, and heart from both infected and control chickens were similar. There was no difference in the DNA content of any of the organs from either infected or control hatchling chickens.

\section{CELLULAR REPLICATION}

Cells were removed from three replicate cultures with $0.1 \%$ trypsin $24 \mathrm{hr}$ after plating and on days 2, 5, and 7. The dispersed cells were counted in a standard hemocytometer chamber. The replication of cells cultivated from infected and control brain, heart, and skeletal muscle at 12 and 20 days of incubation was similar.

Cells cultivated from normal 12- and 20-day-old chicken embryo brain, heart, and skeletal muscle, then infected in vitro, multiplied in the same fashion as uninfected cells. No cytopathic effect was noted in any mumps virus-infected cultures.

\section{CELLULAR METABOLISM}

Of the several organs analyzed, only the cell population cultivated from the bursas of 12-day-old chicken embryos infected in ovo at 16-18 hr of age demonstrated a difference in isotopic incorporation. There was greater incorporation of all three radiolabeled precursors by bursal cells, particularly the uptake of leucine (Fig. 1). The DNA, RNA, and protein metabolism of cells cultivated from the organs of 20-day-old embryos which had been infected in ovo was the same as that of control embryos. The infection of cells cultivated from normal 12- and 20-day embryos did not alter nucleoprotein metabolism.

\section{VIRAL REPLICATION}

Viral assay of organs removed from infected embryos throughout the last half of incubation disclosed that the highest titers of virus were found in the heart (Fig. 2). This experiment was repeated several times and the heart was the only organ which contained persistently higher titers of virus. Intermediate titers of virus were recovered from the lung, spleen, and skeletal muscle, and the lowest quantities of virus were found in the brain and liver. The bursa of Fabricius contained high titers of virus midway through incubation but the quantity of virus decreased to the lowest level as the embryos approached hatch.

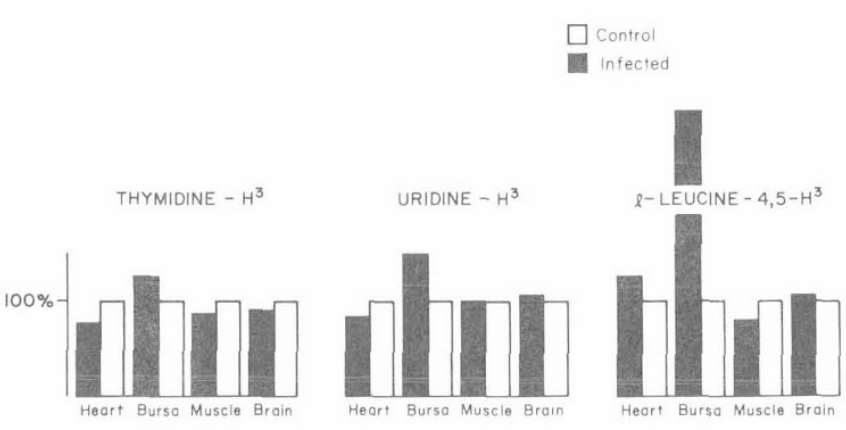

Fig. 1. DNA, RNA, and protein metabolism in cells cultivated from infected and control embryonic organs at 12 days of incubation. The uptake of isotopically labeled precursors by uninfected cells represents an arbitrary $100 \%$.

Table 1. Biochemical variables of chick embryo growth ${ }^{1}$

\begin{tabular}{|c|c|c|c|c|c|c|c|c|c|c|c|c|c|c|c|c|c|c|c|c|c|}
\hline & \multirow[b]{2}{*}{$\begin{array}{l}\text { Body } \\
\text { wt, g }\end{array}$} & \multicolumn{4}{|c|}{ Carcass } & \multicolumn{4}{|c|}{ Brain } & \multicolumn{4}{|c|}{ Liver } & \multicolumn{4}{|c|}{ Kidney } & \multicolumn{4}{|c|}{ Heart } \\
\hline & & $\mathrm{Wt}, \mathrm{g}$ & RNA & DNA & $\begin{array}{l}\text { Pro- } \\
\text { tein }\end{array}$ & Wt, g & RNA & DNA & $\begin{array}{l}\text { Pro- } \\
\text { tein }\end{array}$ & Wt, g & RNA & DNA & $\begin{array}{l}\text { Pro- } \\
\text { tein }\end{array}$ & Wt, g & RNA & DNA & $\begin{array}{l}\text { Pro- } \\
\text { tein }\end{array}$ & Wt, g & RNA & DNA & $\begin{array}{l}\text { Pro- } \\
\text { tein }\end{array}$ \\
\hline \multirow{3}{*}{ Control } & 43.7 & 16.1 & 145 & 26.7 & 4.6 & 685 & 3.8 & 2.1 & 146.7 & 580 & 6.6 & 3.1 & 144 & 150 & 1.4 & 1.6 & 256 & 193 & 1.6 & 1.6 & 46.5 \\
\hline & \pm 1.0 & \pm 2.3 & \pm 60 & \pm 9.3 & \pm 0.8 & \pm 140 & \pm 0.9 & \pm 1.6 & \pm 50 & \pm 106 & \pm 1.6 & \pm 1.2 & \pm 74 & \pm 40 & \pm 0.4 & \pm 0.8 & \pm 8.8 & \pm 46 & \pm 0.5 & \pm 0.65 & \pm 19.2 \\
\hline & $(19)^{2}$ & (6) & (6) & (6) & (6) & (19) & (19) & (19) & (19) & (19) & (19) & (19) & (18) & (19) & (19) & (19) & (19) & (19) & (18) & (19) & (19) \\
\hline Infected & (8) & (5) & (5) & (5) & (5) & (8) & (8) & (8) & (8) & (8) & (7) & (7) & (7) & (8) & (8) & (8) & (7) & (8) & (8) & (8) & (8) \\
\hline$P$ & $<0.005$ & $<0.05$ & $<0.05$ & $\mathrm{NS}^{3}$ & $<0.05$ & $<0.05$ & $<0.05$ & NS & $<0.05$ & NS & NS & NS & NS & NS & NS & NS & $<0.05$ & NS & NS & NS & NS \\
\hline
\end{tabular}

${ }^{1}$ Body, carcass weight and carcass protein are expressed in grams, all other measurements are in milligrams, $\pm 1 \mathrm{SD}$.

${ }^{2}$ Numbers in parentheses represent total numbers of chicks or organs assayed.

${ }^{3} \mathrm{NS}$ : not significant. Statistical computation by Student $t$ test. 


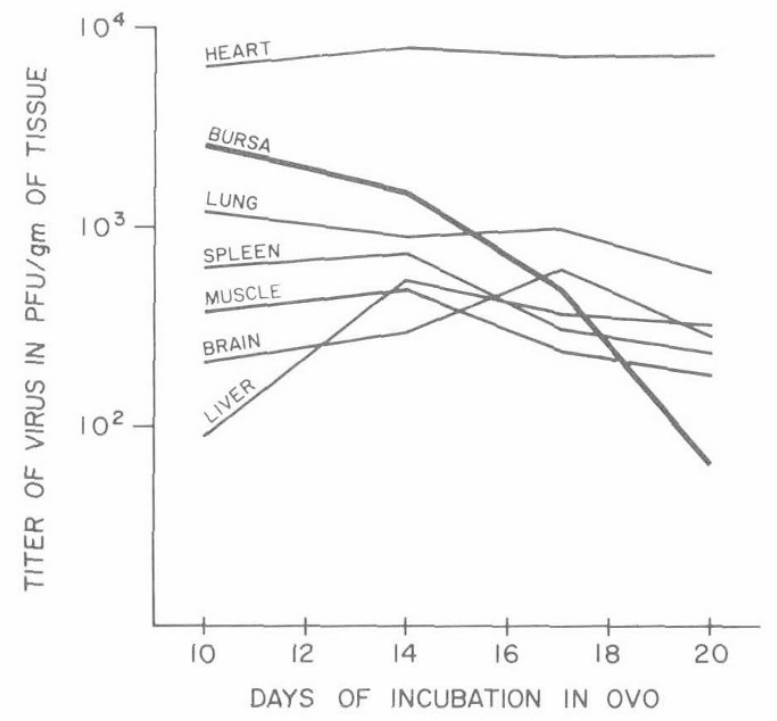

Fig. 2. Replication of mumps virus in chick embryo organs throughout the last half of incubation.

\section{DISCUSSION}

Embryonic viral infections have been implicated as a cause of fetal growth retardation. Gregg (11) in 1941 first reported Iow birth weight as a sequelae to maternal rubella infection. Other investigators $(6,18,19)$ further substantiated the association between maternal rubella infection and infants with subnormal height, weight, and head circumference. Cytomegalovirus infections in the pregnant mother may also lead to the delivery of an infant whose only abnormality is low birth weight (30). Stan and Gold (26) found many of these small-for-gestational age infants were excreting cytomegalovirus. The mechanism or mechanisms for this growth retardation have not been well defined. Plotkin et al. (23) demonstrated that the growth of rubella virus inhibited the replication of cells in vitro. Naeye and Blanc (22) showed that congenital rubella infants were small because of decreased cell number rather than a diminution of cell size.

Using drugs to inhibit DNA and protein synthesis in the pregnant rat, Klionsky and Wigglesworth (15) were able to produce fetal growth retardation. By inhibiting DNA synthesis with hydroxyurea, they were able to reduce organ cell population. Inhibition of protein synthesis with cycloheximide reduced mean cell weight without substantial change in cell population. Our experiments were designed to determine whether that altered growth caused by embryonic mumps virus infection was the result of impaired cellular multiplication or decreased cellular size.

The body weight of infected hatchling chickens was significantly less than control birds. Of several organs examined only the brain of infected chickens had significantly lower weight than uninfected chickens. In previous experiments, the chicken brain was the organ most strikingly reduced in weight by embryonic mumps virus infection (27). Equally significant was the decreased RNA and protein content, a reflection of cellular size, in the brain and carcass. However, the DNA content, a measurement of cellular number of infected and control organs, was the same. Because the weight, RNA, and protein of the brain and carcass of infected hatchlings were decreased when compared with uninfected controls, and the kinetics of cellular doubling of infected and control tissues at 12 and 20 days of incubation was equal, it appears that growth retardation in this experimental model results from a decrease in cell size. Furthermore, mumps virus infection of embryonic cells in vitro did not alter cellular division. The weight and DNA and RNA content were similar in kidney tissue from experimental and control chickens. The protein content, however, was less in the experiments and we are unable to explain this discrepancy.

DNA, RNA, and protein synthesis in cells cultivated from organs infected in ovo and noninfected organs were similar with the exception of the bursa of Fabricius which demonstrated increased activity of all three components of nucleic acid and protein metabolism. Cells cultivated from normal 12 and 20-day-old embryonic organs and subsequently infected with mumps virus in vitro incorporated radiolabeled precursors of DNA, RNA, and protein to the same extent as control cultures. Increased metabolic activity in bursa cell cultures was not demonstrable subsequent to infection in vitro. These experiments suggest that mumps virus has no direct cellular effect on DNA, RNA, and protein synthesis but alters cellular biochemistry in some indirect manner. Although Newcastle disease virus, a paramyxovirus closely related to mumps virus, inhibits cellular DNA, RNA, and protein synthesis $(27,28)$, in our experiments only 0.01 to $1 \%$ to the cell population of embryonic organs contained mumps virus (13), and despite high multiplicities of infection in vitro only $1-10 \%$ of cultivated cells produced virus (29), so it is not surprising that the nucleic acid and protein metabolism of such sparsely infected tissues remain unperturbed. Natural human viral infection is very likely of the same quantitative magnitude as our experimental infections.

The interesting observation of high titers of mumps virus recovered from the bursa of Fabricius during midembryonation deserves additional comment. Prior experiments had indicated that the bursa contained little virus at hatch (27). The function of this structure in the synthesis of immunoglobulins and the development of humoral immunity has been elegantly demonstrated by Cain et al. (5) and Kincade and Cooper $(13,14)$. Heretofore, the bursa has not been implicated as a target organ for viral replication using this strain of mumps virus. The quantity of virus in the bursa decreases as the embryo approaches hatch, whereas viral titers remain high in other tissues. In light of the increased metabolic activity of the bursa one might speculate that viral infection in ovo initiated some mechanism within the bursa for elimination. Currently, studies are underway to determine whether early embryonic viral infection reduces the population of immunoglobulin-producing cells in the bursa.

The sharp rise in mortality for infected embryos near the end of incubation raises another point of speculation. Since mumps virus infection did not alter cellular metabolism, the direct effect of virus on the cell seems minimal. However, experimental embryonic mumps virus infection does cause myocarditis during the late phase of incubation (28). The finding of the highest titers of mumps virus in the chicken embryonic heart throughout the last half of incubation is important and conforms nicely with the histopathologic pattern of eventual myocarditis. In the placentated experimental models, uterine vessel ligation produces placental insufficiency, decreased vascular and nutritional perfusion of the fetus, and ultimate growth retardation. This pathophysiologic disturbance of the placental-fetal unit may have some bearing on the mumps virus-infected chicken embryo. The myocarditis which develops in the aging embryo may alter cardiac function to such an extent that tissue hypoperfusion occurs leading to an increased rate of mortality before hatch or, in the survivors, growth retardation. This growth retardation is especially evident in the brain and is characterised by a decreased RNA and protein content. Therefore, the stunted growth exhibited in this model appears to be the result of diminution in cell size rather than decreased cell number.

\section{REFERENCES AND NOTES}

1. Alford, C. A., Jr., and Kanich, L. S.: Congenital rubella: A review of virologic and serologic phenomena after maternal rubella in 
the first trimester. South. Med. J., 59: 745 (1966).

2. Bellanti, J. A., Artenstein, M. S., Olson, L. C., Buescher, E. L., Luhrs, C. E., and Milstead, K. L.: Congenital rubella: Clinicopathologic, virologic, and immunologic studies. Amer. J. Dis. Child., 110: 464 (1965).

3. Benirschke, K., and Brown, W. H.: A vascular anomaly of the umbilical cord. Obstet. Gynecol., 6: 399 (1955).

4. Burton, K.: A study of the conditions and mechanisms of the diphenylamine reaction for the colorimetric estimate of desoxyribonucleic acid. Biochem. J., 62: 315 (1956).

5. Cain, W. A., Cooper, M. D., Van Alten, P. J., and Good, R. A. Development and function of the immunoglobulin-producing system. J. Immunol., 102: 671 (1969),

6. Cooper, L. Z., Green, R. H., Kingman, S., Giles, J. P., and Mirick, G. S.: Neonatal thrombocytopenia purpura and other manifestations of rubella contracted in utero. Amer. J. Dis. Child., 110: 416 (1965).

7. Davis, C. W. C., and St. Geme, J. W., Jr.: A rapid hemadsorption plaque assay for mumps virus. Proc. Soc. Exp. Biol. Med., 136: 1319 (1971).

8. Davis, C. W. C., St. Geme, J. W., Jr., and Dufour, F.: Mumps virus myocarditis analyzed in vitro. Submitted for publication.

9. Emmanouilides, G. C., Townsend, D. E., and Bauer, R. A.: Effects of single umbilical artery ligation in the lamb fetus. Pediatrics, 42: 919 (1968).

10. Finkel, M. J.: Human growth hormone. Amer. J. Med., 32: 588 (1962).

11. Gregg, N. Ms: Congenital cataract following german measles in mother. Trans. Aust. Coll. Ophthalmol., 3: 35 (1942).

12. Hand, R., Ensminger, W. D., and Tamm, I.: Cellular DNA replication in infections with cytocidal RNA viruses. Virology, 44: 527 (1971).

13. Kincade, P. W., and Cooper, M. D.: Development and distribution of immunoglobulin-containing cells in the chicken. J. Immunol., 106: 371 (1971).

14. Kincade, P. W., and Cooper, M. D.: Immunoglobulin A: Site and sequence of expression in developing chicks. Science, 179: 398 (1973).

15. Klionsky, B., and Wigglesworth, J. S.: Production of experimental models of foetal growth retardation by inhibition of DNA or protein synthesis. Brit. J. Exp. Pathol., 51: 361 (1970).

16. Lancz, G. J., and Johnson, T. C.: Inhibition of protein synthesis in Newcastle Disease virus infected L cells. Proc. Soc. Exp. Biol. Med., 137: 1405 (1971).

17. Lowry, O. H., Rosebrough, N. J., Farr, H. L., and Randall, R. J.: Protein measurement with the Folin phenol reagent. J. Biol. Chem., 193: 265 (1951)

18. Lundstrom, R.: Rubella during pregnancy. Acta Paediat. Suppl., 133: 1 (1962).

19. Lundstrom, R., and Ahnsjo, S.: Mental development following maternal rubella: A followup study of children born in 1951-1952. Acta Paediat. Suppl., 135: 153 (1962).

20. Naeye, R. L.: Malnutrition, a probable cause of fetal growth retardation. Arch. Pathol., 79: 284 (1965).
21. Naeye, R. L.: Anatomical features of growth failure in congenital heart disease. Pediatrics, 39: 433 (1967).

22. Naeye, R. L., and Blanc, W.: Pathogenesis of congenital rubella. J. Amer. Med. Ass., 194: 109 (1965).

23. Plotkin, S. A., Boué, A., and Boué, J. G.: The in vitro growth of rubella virus in human embryo cells. Amer. J. Epidemiol., 81: 71 (1965).

24. Scott, K. E., and Usher, R.: Fetal malnutrition: Its incidence, causes and effects. Amer. J. Obstet. Gynecol., 94: 951 (1966).

25. Smith, C. A.: Effects of maternal undernutrition upon the newborn infant in Holland (1944-1945). J. Pediat., 30: 229 (1947).

26. Starr, J., and Gold, E.: Congenital cytomegalovirus infection associated with low birth weight. J. Pediat., 74: 815 (1969).

27. St. Geme, J. W., Jr., Davis, C. W. C., Peralta, H. J., Farias, N. E., Yamauchi, T., and Cooper, M. D.: The biologic perturbations of persistent embryonic mumps virus infection. Pediat. Res., 7: 541 (1973).

28. St. Geme, J. W., Jr., Peralta, H., Farias, N. E., Davis, C. W. C., and Noren, G. R.: Experimental gestational mumps virus infection and endocardial fibroelastosis. Pediatrics, 48: 821 (1971).

29. Webb, J.: A sensitive method for the determination of ribonucleic acid in tissues and microorganisms. J. Biol. Chem., 221: 635 (1956).

30. Weller, T. H.: The cytomegaloviruses: Ubiquitous agents with protean clinical manifestations. New Engl. J. Med., 285: 204 (1971).

31. Wigglesworth, J. S.: Experimental growth retardation in the foetal rat. J. Pathol. Bacteriol., 88: 1 (1964).

32. Zeman, F. J., and Stanbrough, E. C.: Effect of maternal protein deficiency on cellular development in the fetal rat. J. Nutr., 99: 274 (1969).

33. Mission Farms, Downey, Calif., and Health Research Laboratory, Redmond, Wash.

34. Amersham/Searle Laboratories, Des Plaines, Ill.

35. Falcon Plastics, Los Angeles, Calif.

36. The authors wish to express their gratitude to Mrs. Hawley L. Martin for her expert technical assistance and Mrs. Jenny Keshishian and Mrs. Lu Villarreal for preparation of the manuscript

37. Dr. T. Yamauchi is a former Postdoctoral Trainee, United States Public Health Service, in Pediatric Microbiology and Immunology.

38. This work was supported in part by United States Public Health Service Training Grant no. Tol AI 00367 from the National Institute of Allergy and Infectious Disease, Research Grant no. HD 4610-04 from the National Institute of Child Health and Human Development, and the Los Angeles Heart Association.

39. Requests for reprints should be addressed to: T. Yamauchi, M.D., Harbor General Hospital, UCLA School of Medicine, 1000 W. Carson St., Torrance, Calif. 90509 (USA).

40. Accepted for publication July 29, 1974. 